\title{
Effect of Covid19 on the foreign direct investment (FDI) in the Nigerian economy
}

\author{
Ogundipe S.A *, Fasola I.O ${ }^{* *}$, Ajayi O.A. ${ }^{* * *}$ \\ ${ }^{*} \mathrm{PhD}$;; FCIB \\ ${ }^{* *} \mathrm{PhD}$ \\ ${ }^{* * *} \mathrm{PhD}$;;FCIB
}

DOI: 10.29322/IJSRP.11.09.2021.p11726

http://dx.doi.org/10.29322/IJSRP.11.09.2021.p11726

\begin{abstract}
There is no doubt that the emergence of Cocid-19 has led to unprecedented level of fatalities and with catastrophic effects on human and economic entities on global scale. This invariably has shrunken the level of foreign direct investment into the Nigerian economy. Therefore, the study examined the effect of Covid-19 pandemic on FDI in the Nigerian economy using data of FDI flows into Nigeria from the third quarter of 2013 to the third quarter of 2020. The validated data used for the study was obtained from the Nigerian Bureau of Statistics (NBS). Findings from the trend analysis show that FDI flows into Nigeria have been on a decline over the years before the Covid-19 pandemic reared its ugly head in Q1 2020. In conclusion, the trend of FDI and Covid-19 has not really established a realistic pattern to determine the effect of Covid-19 on FDI in Nigeria. The study may induce more benefit if the analysis of the effect of Covid 19 could be linked to more constantly occurring microeconomic issues for extensive analysis of global pandemic.
\end{abstract}

Index Terms- Covid-19, Foreign direct investment, Nigerian economy.

\section{INTRODUCTION}

$\mathrm{T}$ he corona virus outbreak, which later became a pandemic, hit the world like a thunderbolt towards the end of December 2019. At its inception in Wuhan city in China, it was regarded as a regional health challenge whose global potential risk was summarily underestimated. Although, many countries were in solidarity with China upon this health disaster, Covid-19 was nonetheless not perceived as a threat with a global scale. In fact, the World Health Organization (WHO) declared that the health crisis in China had no global potential threat. However, given that the modern world is entrenched in the concept of globalization and the position of China as the manufacturing hub of the world; a seemingly less risky Chinese health issue metamorphosed into a global scale with lethal consequences (Price and van Holm, 2020; Ezeaku and Asongu, 2020). Scientific analysis of phylogenetic of these viral proteins shows that the Covid-19 virus does not closely resemble any of the three previously known groups of coronaviruses. Phylogenetic analysis of full-length genome sequences obtained from infected patients showed that SARS$\mathrm{CoV}-2$ is similar to severe acute respiratory syndrome coronavirus (SARS-CoV) and uses the same cell entry receptor, angiotensinconverting enzyme 2 (ACE2), as SARS-CoV. Hence, research has shown that without a therapeutic vaccine or specific antiviral drugs, early detection and isolation become essential against novel Coronavirus (Wang et al, 2020), hence, the genome sequence is being worked upon for the diagnosis of SARS virus infection in humans and in detecting animals that might be a potential hosts through the use of polymerase chain reaction and immunological tests for developing antiviral drug for this disease while social distancing by the citizens becomes one of the means to avoid the attack of this particular coronavirus.

In December 2020, statistics showed that the confirmed case of Covid-19 in the world is 68,165,877, Africa 1,571,911 and Nigeria 70,669. However, there have been a lot of debates on the reasons for the low cases of Covid-19 recorded in Africa. This seems illogical given the poor state of public health infrastructure, governance structure, porous borders, weak institutions, inter alia, in the region. It was rather argued that the low number of confirmed cases of Covid-19 recorded in Africa was due to low testing capacity and not necessarily because of location or the effectiveness of containment policies. But the attention of many has been to understandably focus on the short-run effect of Covid19 on several economic variables. (World Bank, 2020; OECD, 2020; Diop and Asongu, 2020)

The trend so far indicates that most cases and deaths were being reported in developed countries where there is better access stronger health care and infection control systems in comparison to the developing countries (Worldometer, 2020). To worsen the situation, individuals with signs and symptoms or suspected to have coronavirus disease may hide in the community because of the fear of stigma, discrimination, and social and economic isolation (Jefferson, 2020).

To contain a pandemic such as the Coronavirus Disease 2019 (COVID-19) pandemic, containment measures including lockdown, business closure, and social distancing are implemented to save lives. However, the containment measures cause uncertainty in economic activities, and result in social, economic, financial and political consequences (Brodeur et al. 2020; Fernandes 2020; Tisdell 2020).

As with almost all countries around the world, Nigeria has faced a barrage of daunting external factors such as lower foreign demand arising from the global recession, which, among other impacts, has led to a slump in oil exports. Similarly, Private investors have also become more risk-averse, resulting in falling foreign investment growth rates (World Bank Group,2020).

To deal with the spread of Covid-19, several governments across the world have taken stringent public health measures to 
limit the spread of the pandemic. These measures include boarder closure, airspace closure and economic lockdown. These measures have caused severe economic disruptions that impact the flow of Foreign Direct Investment (FDI) into emerging economies. Many governments have also taken several important economic policy actions to forestall, or cushion, the economic consequences of the public health crisis with the eventual impact on FDI flows depending on the success of both these public health and economic policy responses (OECD, 2020). Also, Alfaro and Chen (2012) asserted that hindsight from past crises shows that foreign-owned companies show greater resilience during crises due to their linkages with, and access to the financial resources of their parent companies. Similarly, Desai et al. (2008) posited that FDI would be particularly very important to emerging and developing economies since other sources of international financing, including portfolio investment, would have fled these economies during the crisis.

According to UNCTAD (2020), the combined effect of public health and economic policies put in place against the pandemic in many of countries appear to restrict the impacts on FDI flows to these economies. This is partly because the primary sector and manufacturing sector, that usually attract the larger share of FDI in these economies, have been particularly hard hit by the pandemic. OECD (2020) opined that contributions to the recovery from FDI can go beyond financing but include more research and development $(\mathrm{R} \& \mathrm{D})$ activities which are usually carried out by multinational corporations and are well-positioned to help governments deal with the effects of the pandemic. Further, OECD (2018) stated that the trans-border partnerships and collaborations between companies can help in finding long-term business solutions, such as ways to resume production without risking workers' health during the pandemic. In the same vein, Cadestin (2018) posited that FDI can also have indirect effects on the local economy (such as second-order effects on the economy) when locally-established multinational corporations are competing with local firms by hiring and training local workers, and facilitating exports.

However, this pandemic came at a time when the world is experiencing a reduction in FDI flows, the second lowest level recorded since 2010. Corporate debt is also at the highest levels when the pandemic started. Research shows that as at the end of 2019, non-financial corporate bonds have lower overall credit quality, higher payback requirements, longer maturities, and inferior covenant protections compared to previous debt cycles (Celik et al, 2020) and this high level of debt could limit the ability of companies to survive the COVID-19 crisis, let alone support their foreign affiliates or pursue new investments. Therefore, rising debt levels and liquidity constraints are some of the factors driving companies to divest some of their foreign operations (Borga et al, 2020).

According to OECD (2020), projections have shown that even under the most optimistic scenario, FDI flows will likely fall by at least 30 percent in 2020 compared to 2019 before returning to pre-crisis levels by the end of 2021 . Hence, the effect of Covid19 on FDI flows will depend on the success of the public health and economic policy measures taken by governments. Under the pessimistic scenario, the drop in FDI flows lasts longer. This paper seeks the review on the effect of the Covid-19 pandemic on FDIs into Nigeria.
Foreign remittances to Nigeria dropped sharply in 2020 due to rising unemployment in advanced economies where the Nigerian diaspora resides, most notably the United States and the United Kingdom, Spain, Italy and other industrialised countries. The pandemic has led to increased unemployment in these countries, causing home remittances to decline. As of June 2020, when international lockdowns were widespread, remittances had contracted by 42 percent year-on-year. Historically, remittances had proven less volatile than other international capital flows (World Bank Group, 2020).

The Nigeria's Net Foreign Portfolio Investment (NFPI) is projected to hit -2.1 percent of GDP in 2020, however, the persistently low levels of Foreign Direct Investment (FDI) have put Nigeria at risk of relying unduly on portfolio capital ("hot money") to keep the financial account afloat (World Bank Group, 2020). The study therefore hypothesized that Covid-19 has no effect on FDI inflow into the Nigerian economy and it adopted theoretical approach that is focused on analysing the effect of Covid-19 on foreign direct investment in the Nigerian economy. The paper compares the expected FDI flows with the actual flow considering Covid-19 to determine if there is any effect of Covid19 on FDI flows to Nigeria.

\section{REVIEW OF THE LITERATURE}

\section{Covid 19}

Covid-19 is referred to as Severe Acute Respiratory Syndromes (SARS) which have affected the human race in several forms. For example, HCoV-OC43 and HCoV-229E are two different types of human coronaviruses. SARS-CoV-2 or HCov19 (Covid-19) is a new disease, caused by a novel coronavirus that has not previously been seen in humans (Centers for Disease Control and Prevention, 2020). Although there is still a dearth of literature on Covid-19 and its effect on FDI, since the ravaging pandemic is still creating havoc across the world, however, the world had been experiencing health pandemic since the Antonine Plague of $165-180$ AD to the Smallpox pandemic in the $15^{\text {th }}$ Century which claimed 56 million lives. However, historical studies on earlier pandemic caused by similar infectious diseases such as Covid-19 date back to the 1918-19 when the world experienced the Spanish Influenza (Spanish Flu) caused by an H1N1 virus with genes of avian origin. This 1918-19 pandemic provides us with a good evidence of the effect of Covid-19 on economies in general and FDI in particular. The past epidemic sheds light on the economic costs especially in the presence or absence of stringent containment policies. Boissay and Rungcharoenkitkul (2020) and Barro et al. (2020) noted the important economic consequences of the 1918 pandemic to include; low sales due to customer sentiments, high cost to the service sector since they are most affected by facemask and social distancing, and strain on economic activities, among others.

To determine the global economic costs of the pandemics, Lee and McKibbin, (2004) estimated that about 0.1percent of world GDP was lost to SARS. Furthermore, Burns et al. (2006) found that about 0.1 percent and 4 percent were lost in global GDP and Asian GDP due to the impact of Avian Influenza. World Bank (2014) focused on the economic consequence of the Ebola epidemic in the West African region and estimated that within the first year of the pandemic, the Ebola virus caused a decline in the 
GDP of Guinea, Liberia and Sierra Leone by about 2.1 percent, 3.4 percent and 3.3 percent respectively.

\section{Foreign Direct Investment}

Foreign direct investment refers to direct investment equity flows in the reporting economy. It is the sum of equity capital, reinvestment of earnings, and other capital. Direct investment is a category of cross-border investment associated with a resident in one economy having control or a significant degree of influence on the management of an enterprise that is resident in another economy. Ownership of 10 percent or more of the ordinary shares of voting stock is the criterion for determining the existence of a direct investment relationship. Data are in current U.S. dollars.

Foreign Direct Investment in Nigeria averaged 933.66 USD Million from 1990 until 2020, reaching an all-time high of 3084.90 USD Million in the fourth quarter of 2012 and a record low of 63.50 USD Million in the fourth quarter of 1990. (World Bank,2021). It also reported that, Nigeria foreign direct investment for 2019 was \$3.30B, a $\mathbf{6 5 . 1 6 \%}$ increase from 2018; Nigeria foreign direct investment for 2018 was $\mathbf{\$ 2 . 0 0 B}$, a $\mathbf{4 2 . 9 8 \%}$ decline from 2017; Nigeria foreign direct investment for 2017 was \$3.50B, a 21.26\% decline from 2016; and Nigeria foreign direct investment for 2016 was $\mathbf{\$ 4 . 4 5 B}$, a $\mathbf{4 5 . 1 9 \%}$ increase from 2015 . Leiva and Shehadi (2020) posited that many companies are seeing reduced profits in 2020; hence they are less concerned about global expansions with negative impact on foreign investment. And in the bid to prevent the shock to supply chains, more foreign investors are likely to consider investing in business and projects nearer to their home countries which would result in "a pausing of activity, re-shoring or the near-shoring of activities" as a means of reducing dependence on global supply chains. Therefore, globalisation may be a regionalised development in the short to medium term (Barklie, 2020, cited by Leiva and Shehadi, 2020). Seric and Hague, (2020) opined that due to due to Covid-19 pandemic, the temporary pause in FDI will affect economies differently and the pace at which each government responses to the pandemic and the time it takes for each economy to recover will largely determine the flow of FDI back in the country. It does appear that emerging economies are likely to experience the slowest recovery of FDI flows because there is the risk that the type of FDI projects that are likely to be delayed or cancelled out rightly are those targeting the emerging economies. Seric and Hague, (2020) also posited that the contraction in global FDI flow is likely to have more dire effect on developing economies that depend largely on FDI inflows because of the economic benefits of those inflows, hence, they have been competing quite fiercely to attract FDI from advanced economies especially to their primary and manufacturing sectors. Similarly, Leiva and Shehadi (2020) asserted that, as part of strategies of getting their economies back on track, many countries are also introducing FDI screening measures to protect national companies from 'destructive buyouts' as the pandemic transforms FDI into predatory merger and acquisition (M\&A) opportunities across the world. This has already started in the developed economies as governments in Australia, Canada, the EU, France, Germany, India, Italy, Japan, Poland, Spain, the UK and the US have all stepped up their foreign investment screening mechanisms to prevent predatory acquisitions.

\section{Empirical Review}

A study conducted on the economic impact of Covid-19 in Nigeria with emphasis on business activities by KPMG (2020) revealed that the pandemic caused shocks to the Nigerian oildependent economy through the shock to global and domestic business activities and demand on the one hand and shock to the oil price on the other hand. The study also opined that the shocks created by the virus has affected the Nigerian economy, and also concluded that, unlike the threat of Ebola, Zika and SARS viruses which faded with time, the social-economic impact of the pandemic might still persist well after vaccine and cure have been found for the virus. Similarly, by Farayibi and Asongu (2020) found that relationship between the increase in the number of infected cases and attendant macroeconomic outcomes are largely insignificant. In other words, the Covid-19 pandemic has insignificant negative impacts on basic macroeconomic variables in Nigeria such as inflation, employment, exchange rate, GDP growth, among others. However, Cuddington, (1993) averred that the recent studies on viruses such as HIV/AIDS (1981), SARS (2003), Swine Flu (2009) MERS (2012) and Ebola (2014) among others have all found significant direct and indirect economic consequences on all the economic agents; individual households, firms and governments while Mckibbin and Fernando, (2020) stated that the disruption to economic activities caused by the pandemics implies that until the development of the vaccines and antiretroviral therapies which helped to reduce the spread of the diseases, countries across the world had to bear the economic costs of this virus.

The early studies conducted on the economic effect of the current Covid-19 pandemic by Boissay and Rungcharoenkitkul (2020) using GDP foregone as the proxy for economic cost of the Covid-19 pandemic based on the comparison between the current GDP forecast and the Covid-19 outlook. Using the US GDP data released on the April 8th, the study estimated output loss of between 5-9 percent for the US and between 4 and 4.5 percent for the global economy due to the Covid-19 pandemic.

Fornaro and Wolf (2020), cited by (OECD, 2020) modelled the impact of Covid-19 on macroeconomic policy as a mean to assess the macroeconomic implications of the pandemic and asserted that Covid-19 would cause a negative supply shock to the world economy by forcing factories to shut down, disrupting global supply chains and causing a short-lived negative supply shock. Loayza and Pennings (2020) also examined the conduct of macroeconomic policy during the Covid-19 pandemic in developing countries and opined that the pandemic showed global public health emergency and economic crisis with consequences that could surpass the global financial crisis of 2008-2009. Further, Seric and Hague (2020) opined that Covid-19 has dramatically impacted globalization, with flows of foreign direct investments (FDI) being affected and governments measures put in place to contain the pandemic resulting in global production networks to experience disruptions on a scale never witnessed before. The study further noted how the pandemic has exposed the global interconnectedness of the flow of goods to the vagaries of international trade, and how countries and companies are rethinking their trade strategies to protect themselves as much as possible from global economic shocks. 


\section{METHODOLOGY}

\subsection{Research Design}

This study adopted theoretical analysis to explain the relationship between Covid-19 cases and the flows of FDI into the country using data collected from Statista.com which contains daily data published by the Nigeria Centre for Disease Control (NCDC), the agency of Nigerian government responsible for releasing daily updates on Covid-19 cases in Nigeria for the period of Feb $28^{\text {th }}$ to December $31^{\text {st }} 2020$. The study also employed data on FDI flows into Nigeria from the third quarter of 2013 to the third quarter of 2020, obtained from the Nigerian Bureau of Statistics (NBS).

\section{DISCUSSION AND ANALYSIS}

The study established trend analysis on the effect of the Covid-19 pandemic on FDI inflows into the Nigerian economy. Starting with quarterly trend analysis of FDI flows into Nigeria as presented in Figure 1, it is observed that the pattern of FDI movement into the country on a quarterly basis from Q3 of 2013 remains constant. However, for the first three quarters of 2020 and the last one quarter of the year typically recording the largest portion of FDI inflows. Specifically, FDI inflow into Nigeria was \$241m in Q1, a decline of 16.7\% from Q4 2019 and 13.3\% from the corresponding quarter of 2019 . This further fell to $\$ 149 \mathrm{~m}$ in Q2 as the country grapples with increasing cases of Covid-19. However, there was a significant jump in Q3 2020 when the country recorded FDI inflows of $\$ 415 \mathrm{~m}$; a quarter-on-quarter increase of $179.2 \%$ and year-on-year of $100.8 \%$.

Figure 1: Nigeria's Quarterly FDI inflows 2013 -2020

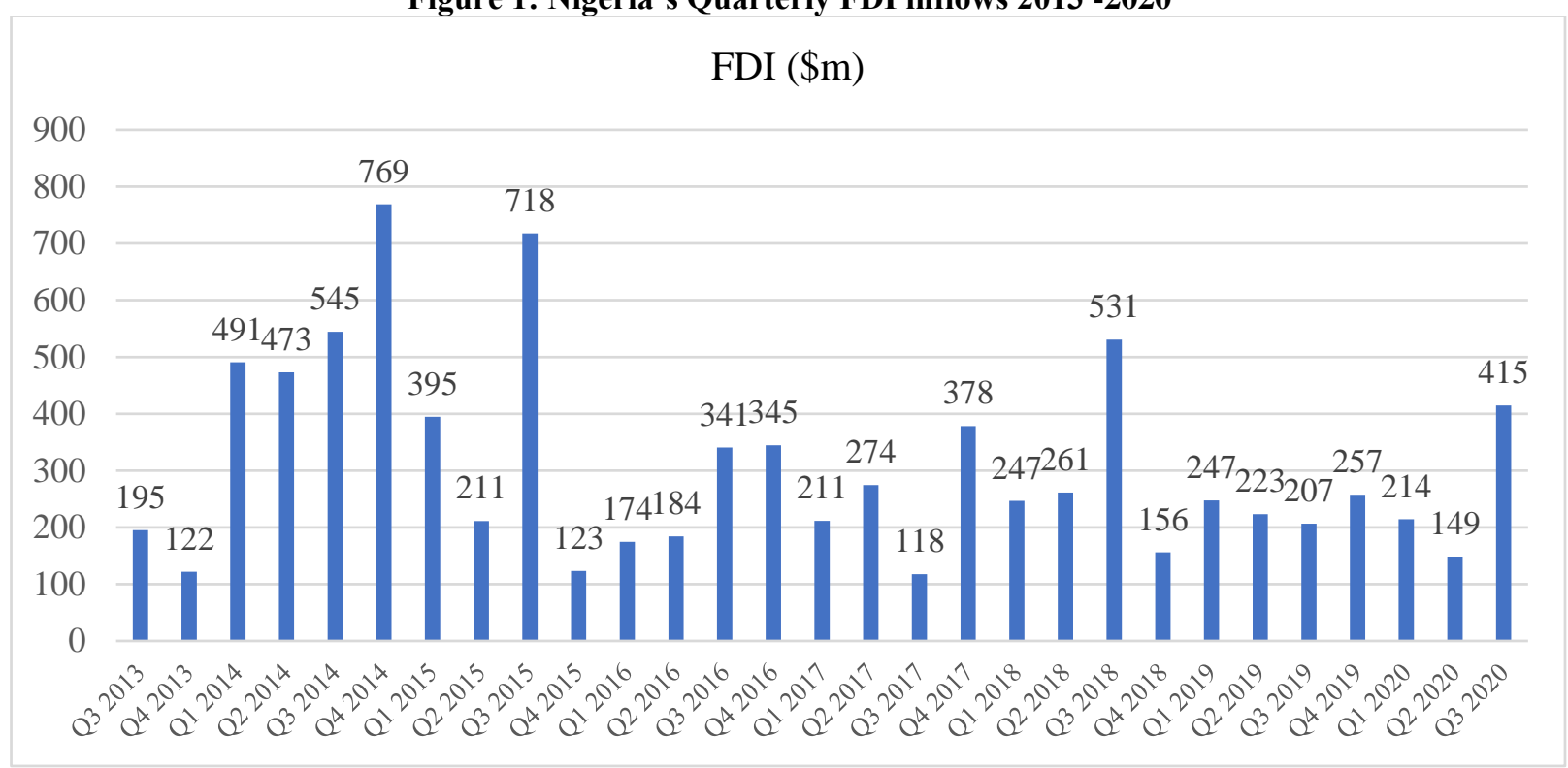

Source: Nigerian Bureau of Statistics

decline of $16.8 \%$ over the total FDI flows from 2019. However,

On a year-on-year basis, Figure 2 shows the trend analysis of the FDI inflows into Nigeria since 2014 to date. From the available data, the country has been experiencing a decline in FDI over the last six years with a compounded annual rate of $16.3 \%$. The FDI inflows for the 9-month period ended Q3 2020 was a compared to 9 months figures for 2019 , the country recorded a growth of $14.9 \%$ in FDI in the 9 months of 2020. 
Figure 2: Nigeria's Annual FDI inflows 2014 -2020

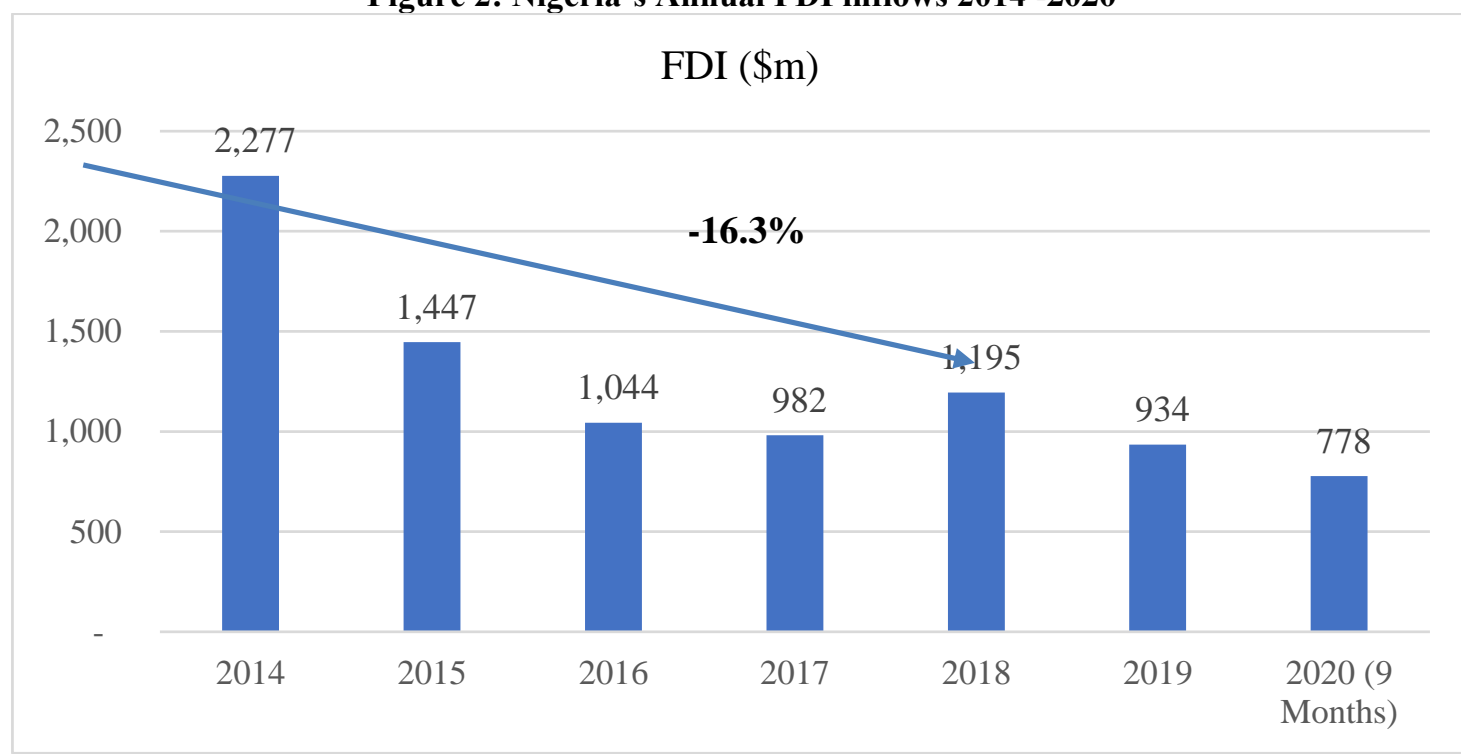

Source: Nigerian Bureau of Statistics

The trend analysis of the Covid-19 cases since the first confirmed case on February $28^{\text {th }} 2020$ is presented below. Figure 3 shows the weekly trend of Covid-19 cases in Nigeria. From the data published by the NCDC, weekly Covid-19 cases was low in the first quarter of the year but surged during the second quarter reaching a peak of 4,269 in the week ending June 27, 2020. Confirmed weekly cases continued to grow until the last weeks in
August when it started to decline. However average weekly cases were 2,500 over the quarter, higher than the average of 1,997 recorded in the second quarter. Weekly reported cases remained low during the early period of the fourth quarter until early December when weekly cases spiked to an average of 4,915 reaching a peak of 6,481 cases during the week ended December, 2020 .

Figure 3: Nigeria's Weekly Covid-19 Cases

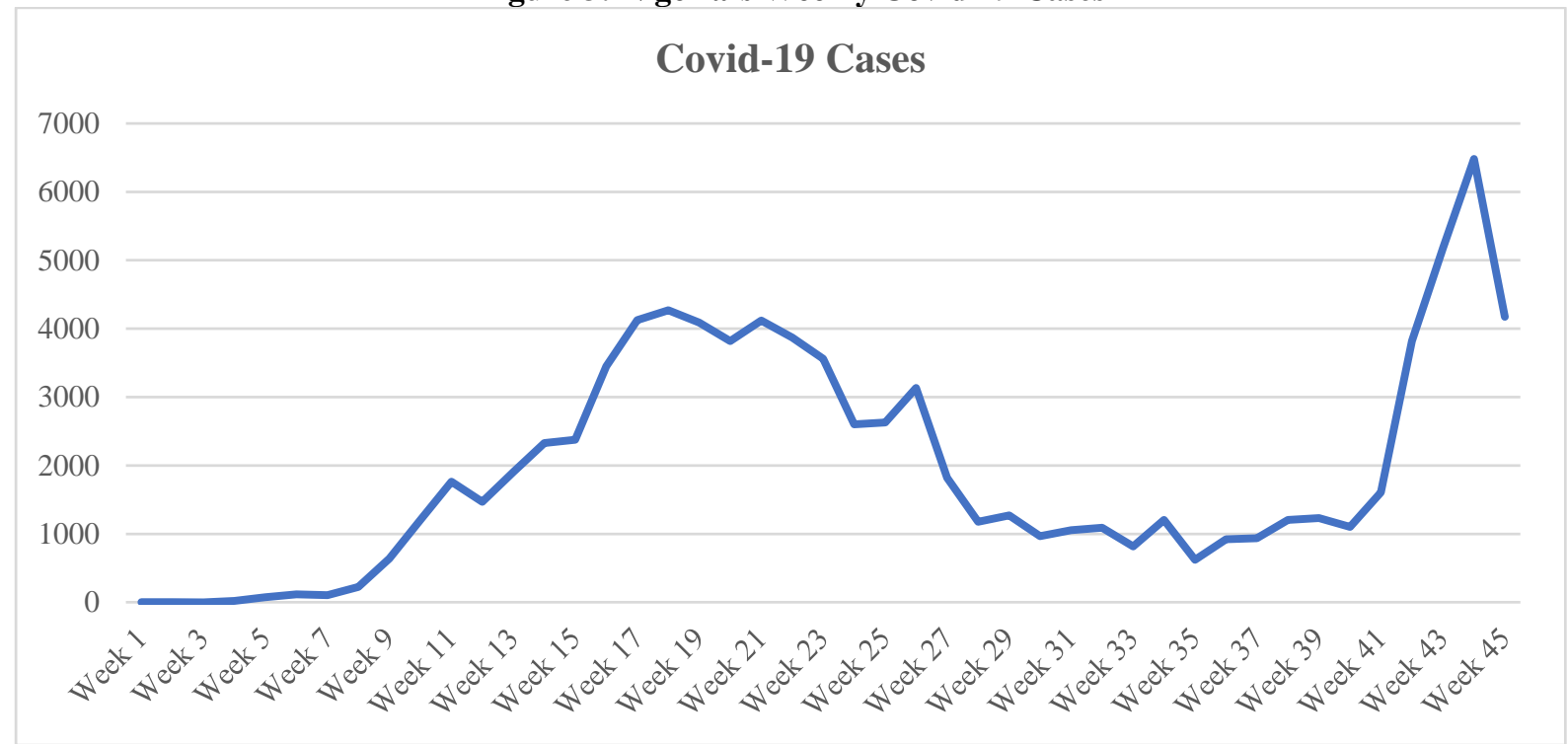

Source: Nigeria Centre for Disease Control

On a quarter-on-quarter basis, confirmed Covid-19 cases grew from 131 in the first quarter to 25563 in the second quarter. This went to 33,154 cases in the quarter before declining slightly to 29,739 in the fourth quarter. Figure 4 below presents the quarterly Covid-19 cases in Nigeria. 
Figure 4i: Nigeria's Quarterly Covid-19 Cases

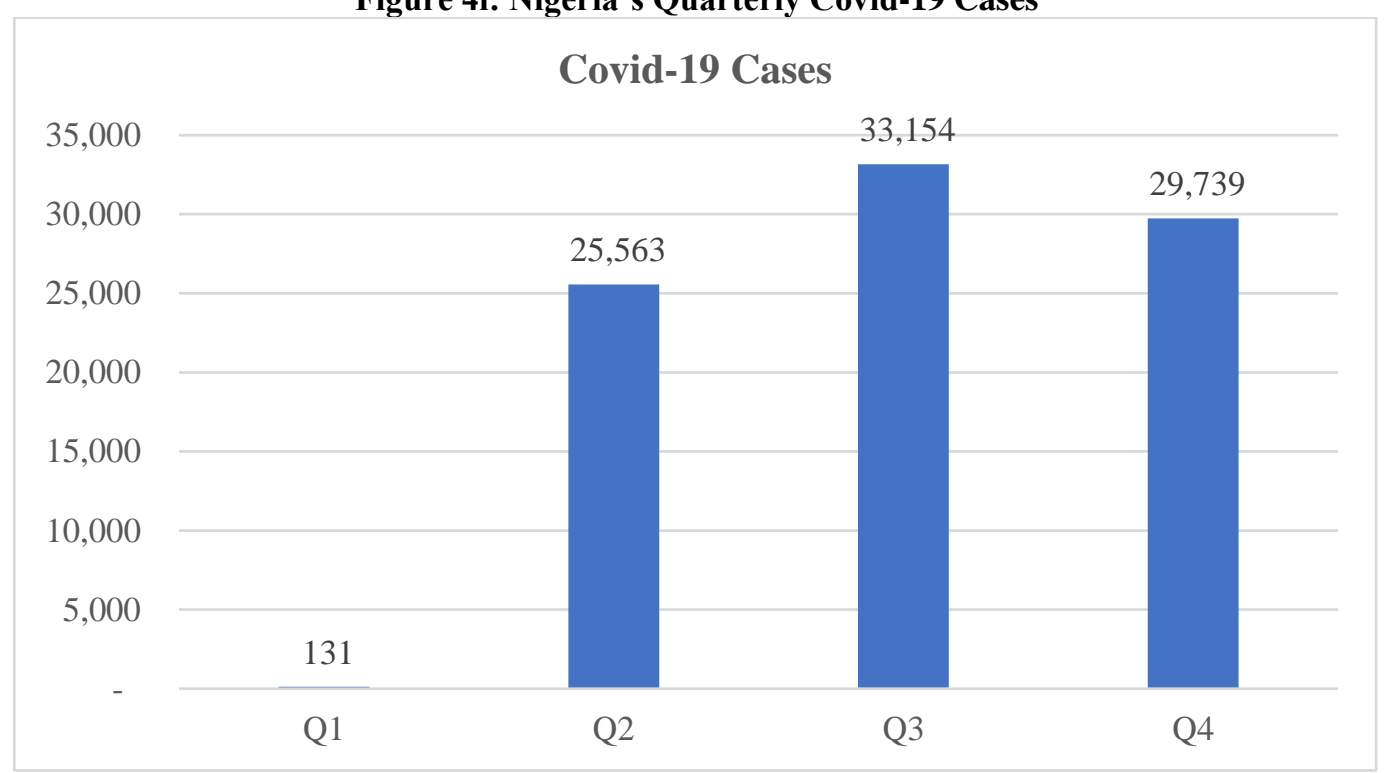

Source: Nigeria Centre for Disease Control

Figure 4ii below shows the trend analysis of the both Covid19 cases and FDI from the first quarter of 2020 to the third quarter of 2020. The trends show clear pattern of relationship between to two variables. While FDI inflows declined from Q1 to Q2, Covid-
19 cases increased during the period, FDI inflow increased quite aggressively in Q3 despite a surge in Covid-19 cases.

Figure 4ii: Nigeria's Quarterly Trend in Covid-19 Cases \& FDI

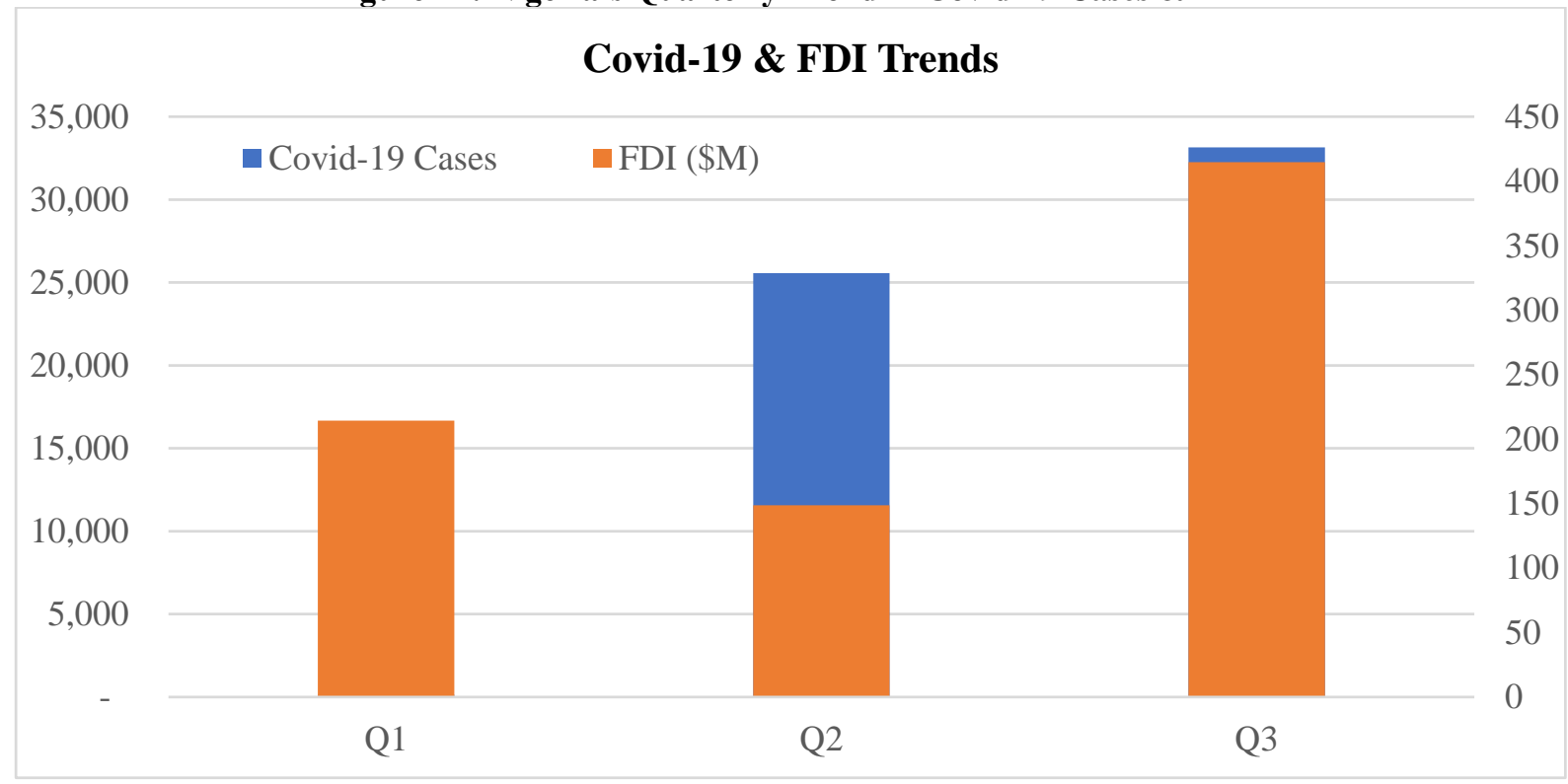

\section{FINDINGS AND CONCLUSIONS}

This study examined the effect of Covid-19 pandemic on FDI in the Nigerian economy. Findings from the trend analysis show that FDI flows into Nigeria have been on a decline over the years before the Covid-19 pandemic reared its ugly head in Q1 2020. In addition, the trend of FDI and Covid-19 has not really established a realistic pattern to determine the effect of Covid-19 on FDI in Nigeria. However, economic variables like FDIs usually have a lag time before causality effect can be established. Therefore, sometime will be required before we can establish proper correlations between the two variables that can withstand empirical scrutiny in terms of causality. The findings of this study clearly leave space for further research to be conducted by obtaining more data to assess if the established correlations can be translated to causality for better policy decision-making. Scholarly 
understanding of the effect of Covid-19 may also benefit more if the examination of the effect could be attached to more constantly occurring microeconomic issues to understand the extensive effect of the global pandemic.

\section{RECOMMENDATION}

The Covid-19 pandemic is not showing any sign of abating, but rather entering the second wave as a result of the relaxation of the lockdown measures earlier put in place by most countries. Nigeria is also experiencing an uptick as can be seen from the recent data which is showing increasing daily confirmed cases. While the fatality rate remains low at about $1.5 \%$, the increase in the rate of transmission and hospitalisation is putting a toll on the country's healthcare system. Nigeria as a destination for foreign direct investment has struggled to attract decent amount of funds in FDI in recent years. This may be due to a lot of reasons including economic management policies such as exchange rate mechanism and needed fiscal policy reforms. The tendency of the Covid-19 pandemic to scare investors away and further reduce FDI inflows into the country requires an understanding of how the pandemic affects the flows of FDI while we await the development of preventive and curative medications to overcome the virus or embrace a new way of life, going forward.

Post Covid-19, economic recovery would require a significant inflow of resources, financial and otherwise, especially in developing countries. This is specifically the role hitherto played by FDI inflows; however, with the contraction in FDI and the competition for the available one, governments would have to develop strategies and policies to help attract and retain the needed FDI and ensure the maximization of their benefits for economic development. Therefore, the pandemic and its effect on FDI may be an opportunity for governments in developing countries to reexamine their approaches to attraction and retaining FDI and develop policies to increase the effective use of FDI in their local economies.

\section{REFERENCES}

[1] Alfaro, L., \& Chen, M. (2012). Surviving the Global Financial Crisis: Foreign Ownership and Establishment Performance. American Economic Journal. Economic Policy, 4(3), 30-55.

[2] Barro, R., Ursua, J., \& Weng, J. (2020). The Coronavirus and the Great Influenza Pandemic: lessons from the'Spanish flu' for the coronavirus' potential effects on mortality and economic activity. NBER Working Paper, No 26866, Cambridge.

[3] Boissay, F., \& Rungcharoenkitkul, P. (2020). Macroeconomic effects of Covid-19: an early review. Bank for International Settlements Bullettin. ISBN: 978-92-9259-369-8.

[4] Borga, M., Flores, P. I., \& Sztajerowska, M. (2020). Drivers of Divestment Decisions of Multinational Enterprises -A Cross-country Firm-level Perspective. OECD Working Papers on International Investment, No 2019/03. Retrieved from https://doi.org/10.1787/5a376df4-en

[5] Brodeur, A, David M. G, Anik I, \& Suraiya B. (2020). A Literature Review of the Economics of COVID-19. In IZA Discussion Paper No. 13411. Germany. Institute of Labor Economics.

[6] Burns, A. V., \& Timmer, H. (2006). Evaluating the Economic Consequences of Avian Influenza. World Bank Working Paper, no 47417.
[7] Cadestin, C. (2018). Multinational enterprises and global value chains. New Insights on the trade-investment nexus. OECD Science, Technology and Industry Working Papers, No. 2018/05. doi:https://doi.org/10.1787/194ddb63-en

[8] Celik, S., Dimertas, G., \& Isaksson, M. (2020). Corporate Bond Market Trends, Emerging Risks, and Monetary Policy,. OECD Capital Market Series. Retrieved from https://www.oecd.org/

[9] Centers for Disease Control and Prevention. (2020). About COVID-19. Retrieved from Centers for Disease Control and Prevention: https://www.cdc.gov

[10] Desai, Mihir, C., Foley, F., \& Forbes, K. J. (2008). Financial constraints and growth: multinational and local firm responses to currency depreciation. Review of Financial Studies, 21 (6, 2857-88.

[11] Farayibi, A. O., \& Asongu, S. A. (2020). The economic consequences of the covid-19 pandemic in Nigeria. Brussels: European Xtramile Centre of African Studies.

[12] Fernandes, N. (2020). Economic Effects of Coronavirus Outbreak (COVID19) on the World Economy. In IESE Business School Working Paper No. WP-1240-E.. Barcelona:. [CrossRef]

[13] Jefferson T (2020). Covid 19-many questions, no clear. answers. BMJ Opinion.

[14] Lee, J. W., \& McKibbin, W. (2004). Globalization and Disease; The Case of SARS. Asian Economic Papers , 3(1), 113-131. doi:(ISSN 1535-3516).

[15] Levia, M., \& Shehadi, S. (2020). Will Covid-19 kill FDI? Retrieved from Investment Monitor, https://investmentmonitor.ai

[16] Loayza, N. V., \& Pennings, S. (2020). Macroeconomic Policy in the time of COVID-19: A Primer for Developing Countries. World Bank Research and Policy Brief, No 28, 1-9.

[17] Mckibbin, W. J., \& Fernando, R. (2020). The global macroeconomic impacts of Covid-19: Seven Scenarios. Centre of Excellence in Population Ageing Research, 1-43.

[18] OECD. (2020). Foreign direct investment flows in the time of COVID-19. Paris: OECD.

[19] Seric, A., \& Hague, J. (2020). The World Economic Forum COVID Action Platform. Retrieved from World Economic Forum. https.//www.weforum.org

[20] Tisdell, C.A., (2020). Economic, social and political issues raised by the COVID-19

[21] pandemic. Economic Analysis and Policy 68: 17-28. [CrossRef] [PubMed]

[22] UNCTAD. (2020). The Impact of the COVID-19 Pandemic on Trade and Development: Transitioning to a New Normal. Geneva: United Nations Conference on Trade and Development (UNCTAD).

[23] Wang, H., Li, X., Li, T., Zhang, S., Wang, L., Wu, X., \& Liu, J. (2020). The genetic sequence, origin, and diagnosis of SARS-CoV-2. European Journal of Microbiology \& Infectiuos Diseases, 39(9), 1629-1635. doi.10.1007/s10096-020-03899-4

[24] World Bank. (2014). The Economic Impact of the 2014 Ebola Epidemic Short- and Medium-Term Estimates for West Africa. Washington DC: Mimeo.

[25] World Bank Group, (2020). Rising to the Challenge: Nigeria's COVID Response. Internet.

[26] www.worldbank.org Nigeria Development Update

[27] Worldometer.,(2020). COVID-19 Coronavirus Outbreak. . Retrieved from https// www.

[28] worldometers.info/coronavirus.

[29] World Bank., (2021) Macrotrends LLC

\section{AUTHORS}

First Author - Ogundipe S.A.ogundipea@babcock.edu.ng; (PhD.;FCIB)

Second Author - Fasola I.O. (PhD.) kayodefasola@yahoo.com Third Author - Ajayi O.A., (PhD.;FCIB)lakunleajayi@gmail.com.

\section{APPENDIX I}

This publication is licensed under Creative Commons Attribution CC BY. 


\section{FDI inflows to developing countries}

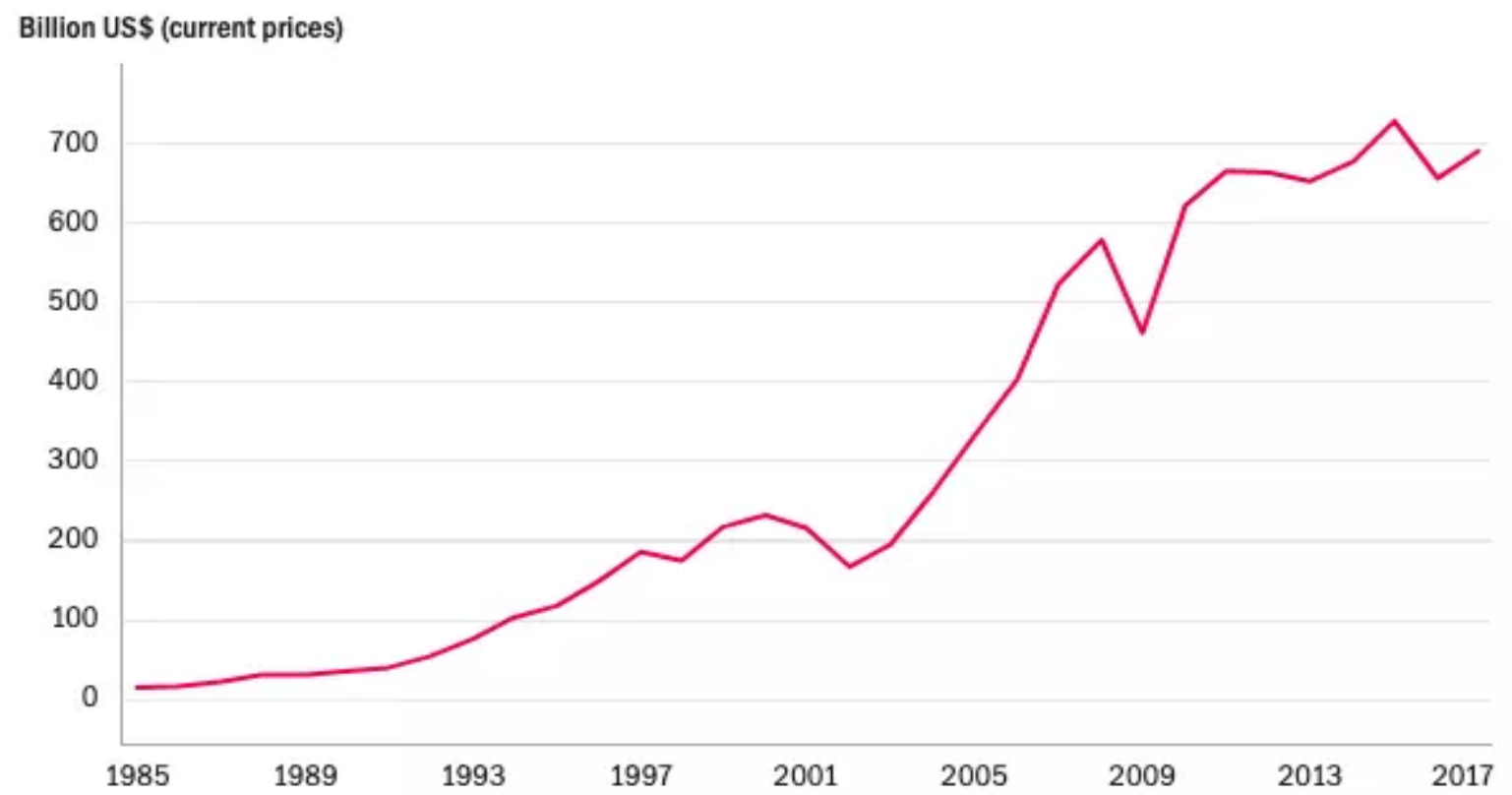

Source: World Economic Forum

- Nigeria Foreign Direct Investment - Historical Data

$\begin{array}{lll}\text { Year } & \text { Inflows, US \$ } & \text { \% of GDP } \\ 2019 & \text { \$3.30B } & 0.74 \% \\ 2018 & \text { \$2.00B } & 0.50 \% \\ 2017 & \text { \$3.50B } & 0.93 \% \\ 2016 & \text { \$4.45B } & 1.10 \% \\ 2015 & \text { \$3.06B } & 0.63 \% \\ 2014 & \text { \$4.69B } & 0.86 \% \\ 2013 & \text { \$5.56B } & 1.09 \% \\ 2012 & \text { \$7.07B } & 1.55 \% \\ 2011 & \text { \$8.84B } & 2.18 \% \\ 2010 & \text { \$6.03B } & 1.67 \% \\ 2009 & \text { \$8.56B } & 2.93 \% \\ 2008 & \text { \$8.19B } & 2.43 \% \\ 2007 & \text { \$6.04B } & 2.19 \% \\ 2006 & \text { \$4.85B } & 2.06 \% \\ 2005 & \text { \$4.98B } & 2.83 \% \\ 2004 & \text { \$1.87B } & 1.37 \% \\ 2003 & \text { \$2.01B } & 1.91 \% \\ 2002 & \text { \$1.87B } & 1.96 \% \\ 2001 & \text { \$1.19B } & 1.61 \% \\ 2000 & \text { \$1.14B } & 1.64 \% \\ 1999 & \text { \$1.00B } & 1.69 \% \\ 1998 & \text { \$0.30B } & 0.55 \% \\ 1997 & \text { \$0.47B } & 0.86 \% \\ & \text { \$0.50B } & 0.98 \% \\ & & \end{array}$


International Journal of Scientific and Research Publications, Volume 7, Issue 8, August 2017 ISSN 2250-3153

- Nigeria Foreign Direct Investment - Historical Data

\begin{tabular}{lll} 
Year & Inflows, US \$ & \% of GDP \\
1995 & \$0.34B & $0.76 \%$ \\
1994 & \$1.96B & $5.79 \%$ \\
1993 & \$1.35B & $4.85 \%$ \\
1992 & \$0.90B & $1.88 \%$ \\
1991 & \$0.71B & $1.45 \%$ \\
1990 & \$0.59B & $1.09 \%$ \\
1989 & \$1.88B & $4.28 \%$ \\
1988 & \$0.38B & $0.76 \%$ \\
1987 & \$0.61B & $1.16 \%$ \\
1986 & \$0.19B & $0.35 \%$ \\
1985 & \$0.49B & $0.66 \%$ \\
1984 & \$0.19B & $0.26 \%$ \\
1983 & \$0.36B & $0.38 \%$ \\
1982 & \$0.43B & $0.30 \%$ \\
1981 & \$0.54B & $0.33 \%$ \\
1980 & \$-0.74B & $-1.15 \%$ \\
1979 & \$0.31B & $0.66 \%$ \\
1978 & \$0.21B & $0.58 \%$ \\
1977 & \$0.44B & $1.22 \%$ \\
1976 & \$0.34B & $0.93 \%$ \\
1975 & \$0.47B & $1.69 \%$ \\
1974 & \$0.26B & $1.03 \%$ \\
1973 & \$0.37B & $2.46 \%$ \\
1972 & \$0.31B & $2.48 \%$ \\
1971 & \$0.29B & $3.11 \%$ \\
1970 & \$0.21B & $1.63 \%$ \\
\hline
\end{tabular}

(C) 2010-2021 Macrotrends LLC | Terms of Service | Privacy Policy | Contact Us 